\title{
Perancangan Sistem Informasi Sentra Pelayanan Kepolisian Terpadu pada Polsek Citeureup Cimahi
}

\author{
Nissa Almira Mayangky ${ }^{1}$ Suharyanto ${ }^{2}$ \\ AMIK BSI Bandung ${ }^{[1]}$ AMIK BSI Bandung ${ }^{[2]}$ \\ Program Studi Manajemen Informatika ${ }^{[1]}$ Program Studi Manajemen Informatika ${ }^{[2]}$ \\ e-mail: nisaalmayangky@gmail.com ${ }^{[1]}$ suharyanto@bsi.ac.id ${ }^{[2]}$
}

\begin{abstract}
Abstrak - Pelayanan merupakan hal yang sangat penting dalam kehidupan manusia, bidang Sentra Pelayanan Kepolisian Terpadu (SPKT) memiliki fungsi diantaranya melayani pengaduan masyarakat yang terkena tindak kriminalitas. Pada Polsek Citeureup Cimahi jika masyarakat melakukan pengaduan kepada kepolisian, pelayanan pada unit SPKT masih menggunakan sistem konvensional belum terkomputerisasi sehingga pada saat proses pelayanan berlangsung masih sering terjadi kesalahan dalam pencatatan, kurang akuratnya laporan yang dibuat, serta lambatnya dalam pencarian data yang diperlukan dan kurangnya informasi kepada masyarakat tentang persyaratan permohonan SSTLP (Surat Tanda Terima Lapor Polisi) Untuk itulah penulis membuat perancangan sistem informasi SPKT yang dapat memudahkan petugas kepolisian dalam proses pembuatan, hingga pengarsipan STTLP, serta dapat memudahkan masyarakat dalam permohonan SSTLP karena data permohonan dan persyaratan di upload melalui sistem SPKT berbasis web. Metode yang digunakan menggunakan metode waterfall dengan menggunakan alat bantu pengembangan sistem berupa DFD, ERD dan LRS. Perancangan sistem ini merupakan solusi yang baik untuk memecahkan permasalahan yang ada pada unit SPKT Polsek Citeureup Cimahi, serta dengan sistem yang terkomputerisasi dapat tercapai suatu kegiatan yang efektif dan efisien dalam menunjang perkerjaan pada instansi.
\end{abstract}

Kata Kunci : Perancangan Sistem Informasi, Pelayanan, Laporan kepolisian

\section{PENDAHULUAN}

Pelayanan adalah kegiatan yang dilakukan seseorang atau sekelompok orang dengan landasan faktor materil melalui sistem, prosedur dan metode tertentu dalam rangka usaha memenuhi kepentingan orang lain sesuai dengan haknya [10]. Melihat kondisi dan fakta di lapangan menggambarkan bahwa pelayanan publik yang diselenggarakan oleh pemerintah masih belum sesuai dengan harapan, masyarakat masih menganggap bahwa pelayanan yang diselenggarakan oleh pemerintah terkesan kurang efektif dan efisien. Instansi pemerintahan yang memberikan pelayanan kepada masyarakat menyangkut masalah dalam hal ketertiban masyarakat, penegakan hukum, perlindungan, pengayoman dilakukan oleh Kepolisian [3].

Kepolisian bidang SPKT (Sentra Pelayanan Kepolisian Terpadu) mempunyai fungsi yang diantaranya melayani pengaduan masyarakat yang terkena tindak kriminalitas yaitu seperti laporan penipuan, perampokan, penggelapan, pencurian, kehilangan barang berharga dan sebagainya. Karena tingginya keluhan masyarakat pada saat ini, masyarakat sangat membutuhkan pelayanan yang cepat di bagian SPKT. Karena SPKT merupakan ujung tombak pelayanan kepolisian dalam memberikan pelayanan kepada masyarakat untuk peningkatan dan memudahkan pelayanan diperlukan perangkat lunak [3].

Pada Polsek Citeureup Cimahi jika masyarakat melakukan pengaduan ataupun permohonan kepada kepolisian unit SPKT (Sentra Pelayanan Kepolisian Terpadu), petugas masih menggunakan sistem konvensional atau belum terkomputerisasi dimana kekurangan dari sistem ini adalah sangat memungkinkan pada saat proses berlangsung terjadi kesalahan dalam pencatatan, kurang akuratnya laporan yang dibuat, keterlambatan dalam pencarian data yang diperlukan STTLP (Surat Tanda Terima Laporan Polisi) maka petugas harus menulis ulang pada buku untuk pengarsipan, kemudian jika masyarakat melakukan permohonan untuk ke dua kalinya petugas harus menulis ulang data pemohon karena membutuhkan waktu lama untuk pencarian data, sementara kesulitan yang dihadapi pemohon adalah kurangnya informasi persyaratan yang harus dilengkapi untuk membuat laporan atau permohonan STTLP sehingga banyak pemohon berulang kali datang ke kantor polisi untuk memenuhi persyaratan yang belum lengkap, Kemudian Kepala Administrasi SPKT mendapatkan laporan secara manual, sehingga pengawasan terhadap SPKT kurang efektif.

Apabila sistem SPKT (Sentra Pelayanan Kepolisian Terpadu) sudah terkomputerisasi, petugas bisa mendapatkan data pemohon dengan mudah dan pengarsipan lebih efektif, sementara kemudahan untuk pemohon yaitu bisa mendapatkan informasi tentang pengaduan dengan jelas, dan pemohon tidak harus antri untuk membuat STTLP karena 
pengisian formulir dan persyatan dilakukan secara online bisa dimana saja. Pengawasan oleh Kepala Administrasi SPKT dapat secara langsung dilakukan dengan melihat laporan yang telah ada pada sistem, sehingga bisa di lihat kapanpun.

Untuk itulah penulis mengambil pembahasan dalam penelitian ini dengan judul "Perancangan Sistem Informasi Sentra Pelayanan Kepolisian Terpadu Pada Polsek Citeureup Cimahi”.

\section{LANDASAN TEORI}

A. Konsep Dasar Sistem Informasi.

Sistem informasi adalah suatu sistem di dalam suatu organisasi yang mempertemukan kebutuhan pengolahan transaksi harian yang mendukung fungsi operasi organisasi yang bersifat menejerial dengan kegiatan strategi dari suatu organisasi untuk dapat menyediakan laporan-laporan yang diperlukan. komponen sistem informasi terbagi menjadi beberapa bagian yang berinteraksi satu dengan yang lain membentuk satu kesatuan untuk mencapai sasaran. [12]

\section{B. Pelayanan Pemerintahan.}

Pelayanan menurut Kamus Besar Bahasa Indonesia adalah membantu menyiapkan atau mengurus apa-apa yang diperlukan seseorang. Pelayanan umum adalah kegiatan yang dilakukan seseorang atau sekelompok orang dengan landasan faktor materil melalui sistem, prosedur, dan metode tertentu dalam rangka usaha memenuhi kepentingan orang lain sesuai dengan haknya. [10]

Pemberian pelayanan umum kepada masyarakat merupakan perwujudan kewajiban aparatur pemerintah sebagai abdi masyarakat. Penyelenggaraan pelayanan harus mengandung unsur Transparansi, Akuntabilitas, Kondisional, Parsitipatif, Kesamaan hak, Keseimbangan hak dan kewajiban. [10]

Kualitas pelayanan/jasa adalah keseluruhan ciri-ciri dan karakteristik-karakteristik dari suatu produk atau jasa dalam hal kemampuannya untuk memenuhi kebutuhankebutuhan yang ditentukan atau bersifat laten. [11]

\section{Sentra Pelayanan Kepolisian Terpadu (SPKT).}

Sentra pelayanan kepolisian (SPK) menerima laporan atau pengaduan kepada Polisi tentang dugaan adanya tindak pidana pada setiap kesatuan kepolisian.

Tugas dari SPKT adalah Memberikan pelayanan Kepolisian secara terpadu kepada masyarakat dalam bentuk penerimaan dan penanganan laporan atau pengaduan, pemberian bantuan atau pertolongan dan pelayanan surat keterangan dan menyajikan informasi yang berkaitan dengan kepentingan tugas kepolisian guna dapat diakses sesuai dengan ketentuan peraturan perundang-undangan. [3]

D. Konsep Dasar Website.
Website adalah keseluruhan halaman-halaman web yang terdapat dalam sebuah domain yang mengandung informasi". Sebuah website biasanya dibangun atas banyak halaman web yang saling berhubungan. Hubungan antara satu halaman web dengan halaman web yang lainnya disebut dengan hyperlink, sedangkan teks yang dijadikan media penghubung disebut hypertext. Fungsi website bermacammacam tergantung dari tujuan dan jenis website yang dibangun fungsi website sebagai media Promosi, Pemasaran, Informasi, pendidikan dan komunikasi. [2].

\section{E. Basis Data.}

Basis data adalah sekumpulan notasi atau simbol untuk menggambarkan data dan relasinya, berdasarkan suatu konsep dan aturan tertentu suatu pemodelan atau sekumpulan fakta berupa representasi tabel yang saling berhubungan dan disimpan dalam media penyimpanan secara digital. [6]

F. Bahasa pemrograman.

Bahasa pemrograman yang digunakan dalam perancangan sistem ini adalah, sebagai berikut:

1. PHP ( PHP Hypertext Preprocessor) PHP adalah bahasa pemrograman web berbasis server (server-side). Artinya, kode ini dijalankan di server, yang memungkinkan anda generate kode HTML secara dinamis, tampilan bisa berubah-ubah sesuai dengan keinginan, dan sangat cocok untuk pengembangan web. [13]

2. HTML Hypertext Markup Language adalah bahasa dari Word Wode Web. Setiap kali mengakses internet atau homepage, sesungguhnya kita mengakses dokumen seseorang yang dibuat menggunakan format HTML. Agar dapat membuat suatu dokumen atau homepage, perlu kita mengetahui sintaks atau tag HTML. [8]

\section{G. Adobe Dreamweaver}

Adobe Dreamweaver merupakan program editor halaman web (web page), aplikasi desain dan pengembangan web yang menyediakan editor WYSIWYG (What You See Is What You Get) visual standar seperti syntax highlighting, cose completion, dan code collapsing, real time syntax checking dan code introspection yang menghasilkan petunjuk kode membantu pengguna dalam menulis kode, memfasilitasi desain dan pembuatan kode tataletak menjadi lebih cepat. Memiliki berbagai fitur yang memudahkan pengguna untuk membangun sebuah website. [1]

H. Diagram Alir Data (DAD)

Diagram Alir Data adalah refresentasi grafik yang menggambarkan aliran informasi dan transformasi informasi yang diaplikasikan sebagai data yang mengatur dari masukan (input) dan keluaran (output). DFD tidak sesuai untuk memodelkan sistem yang menggunakan pemograman berorientasi objek. [9]

I. Entity Relationship Diagram (ERD) 
ERD (Entity Relationship Diagram) adalah sebuah diagram yang secara konseptual memetakan hubungan antar penyimpanan pada diagram DFD di atas. ERD ini digunakan untuk melakukan pemodelan terhadap struktur data dan hubungannya. Penggunaan ERD ini dilakukan untuk mengurangi tingkat kerumitan penyusunan sebuah database yang baik. [5]

\section{J. Logical Record Structure (LRS)}

Logical Record Structured (LRS) LRS adalah representasi dari struktur record-record pada tabel-tabel yang terbentuk dari hasil relasi antar himpunan entitas. Menentukan Kardinalitas, Jumlah Tabel, dan Foreign Key. [5]

\section{K. Model Pengembangan Sistem.}

Salah satu model yang digunakan adalah model air terjun (waterfall). Model ini adalah model klasik yang bersifat sistematis, berurutan dalam membangun software. model SDLC Air terjun (Waterfall) sering juga disebut model sekuensial linier (Sequential Linear) atau alur hidup klasik (classic life cycle). Model ini menyediakan pendekatan alur hidup perangkat lunak secara sekuensial atau beurut. [9]

\section{METODE PENELITIAN}

A. Metode Pengumpulan Data.

1. Observasi

Penulis melakukan observasi atau pengamatan langsung pada Polsek Citeureup Cimahi guna menganalisa sistem berjalan pada unit SPKT (Sentra Pelayanan Kepolisian Terpadu).

2. Wawancara

Penulis mengajukan beberapa pertanyaan yang berhubungan dengan sistem berjalan pelayanan kepolisian kepada Bapak Aiptu Heri dan Bripka Doni Frengky kepala dan staf Sentra Pelayanan Kepolisian Terpadu (SPKT) .

3. Studi Pustaka

Penulis mengumpulkan berbagai referensi, baik yang bersifat on-line (internet) ataupun yang bersifat off-line (buku, jurnal, tugas akhir dan dokumen-dokumen terkait) yang mendukung pembuatan tugas akhir ini.

B. Metode Pengembangan perangkat Lunak.

Metode pengembangan sistem dengan waterfall, akan lebih mudah dalam merancang sistem yang diinginkan dan dapat diterima oleh user sebagai pemakai, penulis menginginkan perancangan sistem yang telah dihasilkan kemudian dipersentasikan kepada user dan user diberikan kesempatan untuk diberikan masukan-masukan sehingga sistem informasi yang dihasilkan benar-benar sesuai dengan yang diinginkan. [7]
1. Analisis kebutuhan perangkat lunak

Pada tahap analisa untuk kebutuhan sistem yang akan dibangun, penulis mengumpulkan data serta dokumen Surat Tanda Terima Laporan Polisi (STTLP) yaitu laporan polisi (LP), Surat Keterangan Tanda Lapor Kehilangan (SKTLK), Surat Tanda Terima Pemberitahuan (STTP), Surat Keterangan catatan kepolisian (SKCK) Program yang penulis gunakan untuk menunjang kebutuhan sistem yang akan dibangun diantaranya Xampp, MYSQL, Macromedia Dreamweaver, Web Browser dan Teks Editor Sublime.

2. Desain

Pada tahap desain, penulis membuat sebuah desain sistem dari hasil analisa yang telah dilakukan menggunakan ERD (Entity Relationship Diagram), LRS (Logical Record Structure) untuk desain database, Dreamweaver, PHP dan Bootsrap CSS Untuk desain antarmuka, Tujuan dari desain sistem ini adalah untuk mempermudah dalam proses pembuatan program.

\section{Implementasi.}

Merupakan tahap dimana semua desain yang telah dirancang diterjemahkan kedalam bahasa pemrograman untuk kebutuhan komputerisasi. Penulis menggunakan bahasa pemrograman PHP (Personal Home Page) dan bahasa SQL (Structure Query Language) untuk mengakses database yang akan dibuat.

\section{PEMBAHASAN}

\section{A. Prosedur Sistem Berjalan}

Sentra pelayanan kepolisian (SPK) sebagaimana dimaksud dalam Peratuan Kepala Kepolisian Negara Republik Indonesia Nomor 12 Tahun 2009 tentang Pengawasan dan Pengendalian Penanganan Perkara Pidana di lingkungan kepolisian Negara Republik Indonesia, bab II Pasal 5 ayat 4. SPK menerima laporan atau pengaduan kepada Polisi tentang dugaan adanya tindak pidana pada setiap kesatuan kepolisian. Tugas dari SPKT adalah Memberikan pelayanan Kepolisian secara terpadu kepada masyarakat dalam bentuk penerimaan dan penanganan laporan atau pengaduan, pemberian bantuan atau pertolongan dan pelayanan surat keterangan dan menyajikan informasi yang berkaitan dengan kepentingan tugas kepolisian guna dapat diakses sesuai dengan ketentuan peraturan perundangundangan [4].

Pelayanan permohonan STTLP (Surat Tanda Terima Laporan Polisi) dibagi menjadi 5 (lima) yaitu, Laporan Polisi (LP), Surat Keterangan Tanda Lapor Kehilangan (SKTLK), Surat Tanda Terima Pemberitahuan (STTP), Surat Keterangan Catatan Kepolisian (SKCK) dan Surat Ijin Keramaian. Berikut Prosedur berjalan pada Sentra Pelayanan Pengaduan Terpadu (SPKT) : 
1. Prosedur Pendataan Persyaratan

Pemohon datang lalu mengisi buku registrasi dan menanyakan informasi tentang persyaratan kepada petugas, kemudian pemohon antri untuk melakukan proses pengaduan dan memberikan persyaratan sesuai dengan jenis laporan Surat Tanda Terima Laporan Polisi (STTLP) kepada petugas kepolisian, yang meliputi STTLP yaitu:

a. Laporan Polisi (LP)

Persyaratan : Memberikan keterangan dan barang bukti.

b. Surat Keterangan Tanda Lapor Kehilangan (SKTLK)

Persyaratan kehilangan Dokumen : Membawa fotokopi dokumen hilang atau memberikan nomor induk dokumen yang hilang

Persyaratan Kehilangan Kendaraan : Membawa Dokumen-dokumen Kendaraan

c. Surat Tanda Terima Pemberitahuan (STTP)

Persyaratan : Membawa surat permohonan dan melampirkan jadwal acara, susunan panitia, nama peserta/undangan, nama pembicara, ad/rt/organisasi, foto copy ktp penanggung jawab, akte pendirian organisasi dan proposal.

d. Surat Keterangan Catatan Kepolisian (SKCK) Persyaratan : Membawa Surat Pengantar Kelurahan/Desa diketahui RT/RW, foto copy Kartu Keluarga (KK), foto copy KTP dan foto ukuran 4x6 $=3$ lembar.

e. Surat Ijin Keramaian

Persyaratan : Surat pengantar dari RT/RW tempat keramaian akan berlangsung.

\section{Prosedur Analisa Pengaduan}

Petugas kepolisian menerima persyaratan dan pengaduan masyarakat, lalu menganalisa laporan dengan keterangan dan barang bukti yang selanjutnya dibuatkan rekomendasi pengaduan sesuai jenis STTLP.

Khusus untuk pembuatan Surat Keterangan Catatan Kepolisian (SKCK) masyarakat diberikan formulir data diri yang harus diisi, setelah itu formulir diberikan kepada petugas lalu dilakukan pengecekan data diri dan data kriminal, kemudian masyarakat diberikan bon pembayaran lalu melakukan pembayaran.

\section{Prosedur Laporan SPKT}

Petugas Kepolisian Urusan Administrasi (URMIN) menerima data pengaduan dan data formulir lalu membuat Surat Tanda Terima laporan Polisi (STTLP) sesuai dengan jenis pengaduan kemudian diberikan kepada masyarakat/pemohon. Kemudian petugas mencatat laporan yang masuk dalam buku register dan melaporkan kepada Kepala Administrasi (KA) SPKT secara berkala.

\section{B B. Perancangan sistem Usulan.}

Rancangan sistem usulan yang penulis buat adalah untuk menambahkan atau memperbaiki prosedur sistem yang sedang berjalan. Adapun rancangan prosedur sistem usulan Sentra Pelayanan Kepolisian Terpadu (SPKT) berbasis web sebagai berikut :

1. Prosedur Pendataan Persyaratan

Pemohon membuka website Sistem Informasi SPKT untuk mendapatkan informasi tentang syarat pemohonan lalu melakukan registrasi dengan mengisi form data diri untuk kemudian melakukan login, setalah login pemohon memilih menu permohonan mana yang akan dibuat, kemudian mengisi form data pemohon dan mengunggah data persyaratan sesuai dengan jenis permohonan Surat Tanda Terima Pemberitahuan (STTLP), setelah itu mencetak bukti formulir online. yang termasuk kedalam jenis STTLP yaitu :

a. Laporan Polisi (LP)

Persyaratan : foto barang bukti.

b. Surat Keterangan Tanda Lapor Kehilangan (SKTLK)

Persyaratan kehilangan Dokumen : Scan dokumen hilang

Persyaratan Kehilangan Kendaraan : Scan dokumen-dokumen kendaraan

c. Surat Tanda Terima Pemberitahuan (STTP)

Persyaratan : Scan permohonan, scan jadwal acara,scan susunan panitia, scan nama peserta/undangan,scan data pembicara,scan $\mathrm{ad} / \mathrm{rt} /$ organisasi, scan foto ktp penanggung jawab, scan akte pendirian organisasi dan scan proposal.

d. Surat Keterangan Catatan Kepolisian (SKCK) Persyaratan : Scan Surat Pengantar Kelurahan/Desa diketahui RT/RW, scan Kartu Keluarga (KK), scan KTP dan foto ukuran $4 \times 6$

e. Surat Ijin Keramaian

Persyaratan : Scan Surat pengantar dari RT/RW tempat keramaian akan berlangsung

2. Prosedur Analisa

Pemohon datang ke kantor kepolisian sembari membawa bukti persyaratan online dan KTP, lalu mengambil nomor antrean. Petugas menganalisa pengaduan dan nomor formulir online, kemudian di proses menjadi STTLP melalui tahap konfirmasi persyaratan dan formulir data diri.

Khusus untuk jenis STTLP pembuatan SKCK ada prosedur tambahan yaitu tahapan pengecekan data kriminal, kemudian pemohon diberikan bon pembayaran dan melakukan proses pembayaran.

3. Prosedur Pembuatan Laporan.

Setelah diterbitkan STTLP kemudian diberikan kepada pemohon. Lalu data pemohon dan data pengaduan akan tersimpan dalam sistem yang kemudian menjadi laporan 
sehingga dapat dipantau oleh Kepala Administrasi SPKT kapan dan dimana saja.

\section{a. Diagram Alir Data Sistem Usulan}

Adapun prosedur sistem usulan untuk Sentra Pelayanan Kepolisian Terpadu (SPKT) Polsek Citeurep yang akan di jelaskan melalui diagram alir data, yaitu :

1. Diagram Konteks Sistem Usulan

Diagram konteks dibawah ini menggambarkan entitas, proses dan aliran data sistem usulan pada Sentra pelayanan Kepolisian Terpadu (SPKT) :

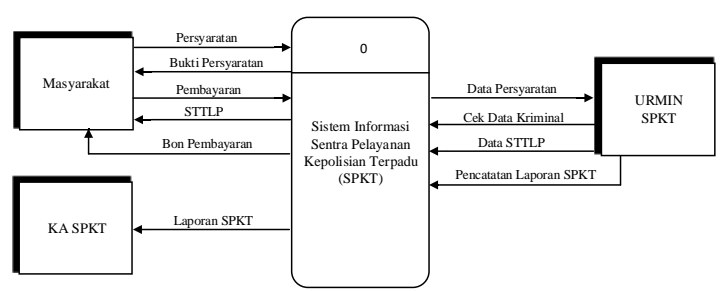

Gambar 1. Diagram Konteks Sistem Usulan

2. Diagram Nol Sistem Usulan

Diagram nol dibawah ini menggambarkan entitas, proses dan aliran data lebih terperinci pada sistem usulan Sentra pelayanan Kepolisian Terpadu (SPKT):

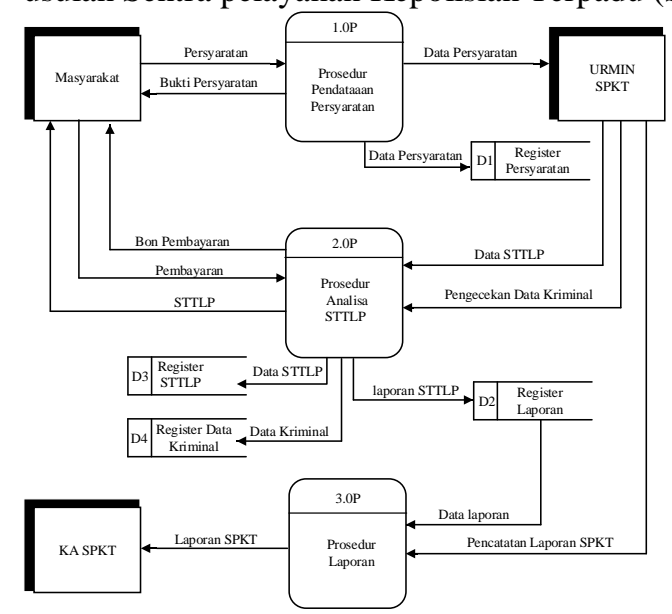

Gambar 2. Diagram Nol Sistem Usulan

3. Diagram Detail Rancangan Prosedur Sistem Usulan Diagram detail diatas menggambarkan entitas, proses dan aliran data lebih terperinci dan lebih mendetail yang belum tergambarkan pada diagram nol pada sistem berjalan Sentra pelayanan Kepolisian Terpadu (SPKT).

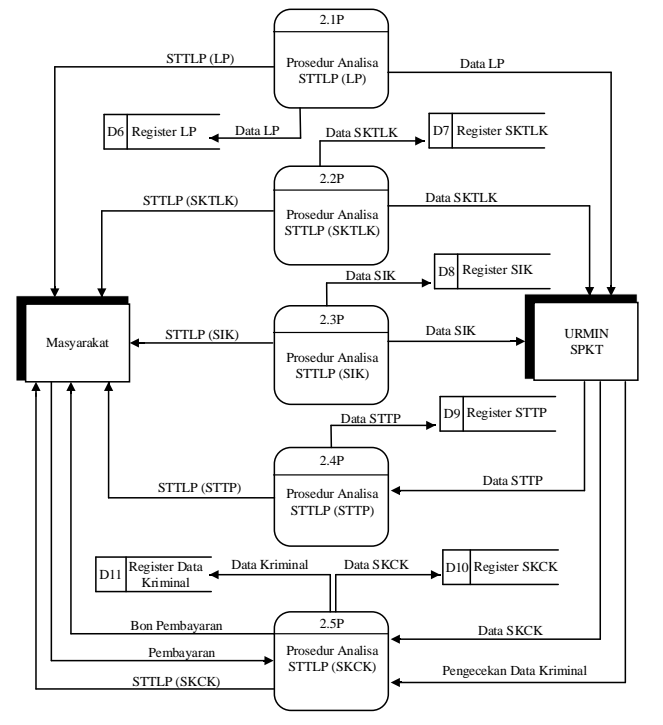

Gambar 3. Diagram Detail Sistem Usulan

\section{b. Entity Relationship Diagram Sistem Usulan}

Perancangan basis data menghasilkan pemetaan tabel-tabel yang digambarkan dengan Entity Relationship Diagram (ERD), ERD yang diusulkan yaitu tampak pada gambar berikut ini:

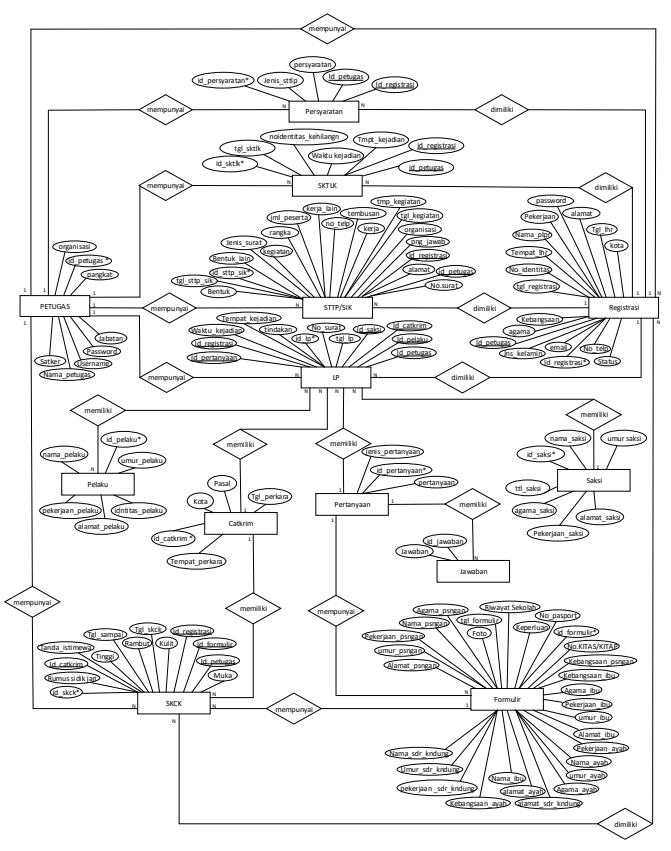

Gambar 4. ERD Sistem Usulan

\section{c. Logical Record Structured (LRS)}




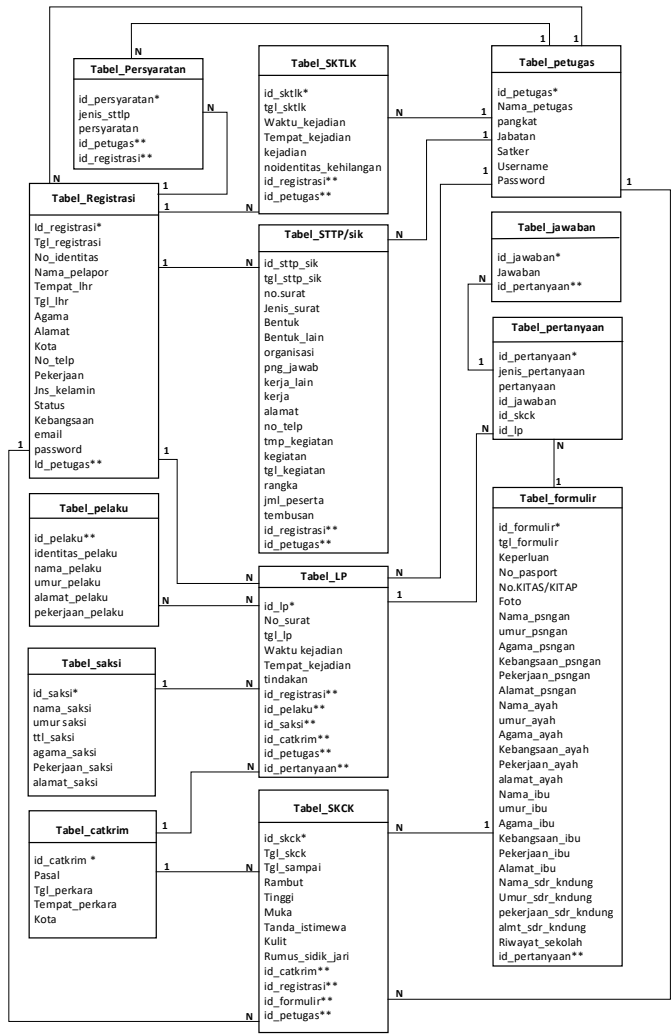

Gambar 5. LRS Sistem Usulan

\section{d. Diagram HIPO Rancangan Aplikasi SPPKT.}

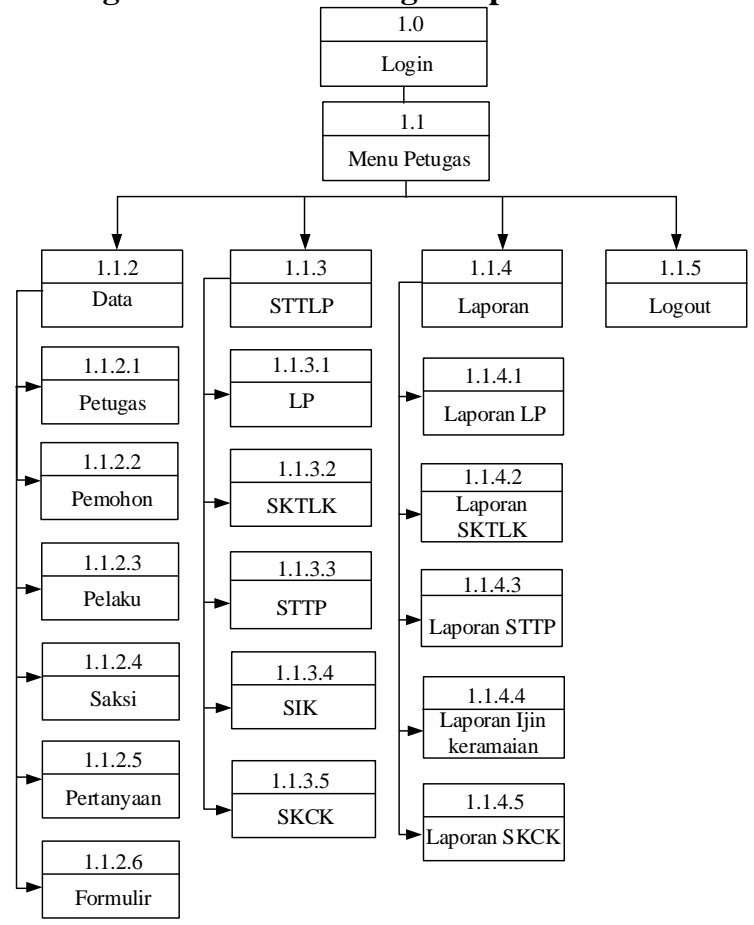

Gambar 6. Diagram HIPO Sistem Usulan

\section{Implementasi.}

1. Spesifikasi Rancangan Tampilan Program Menu Utama.

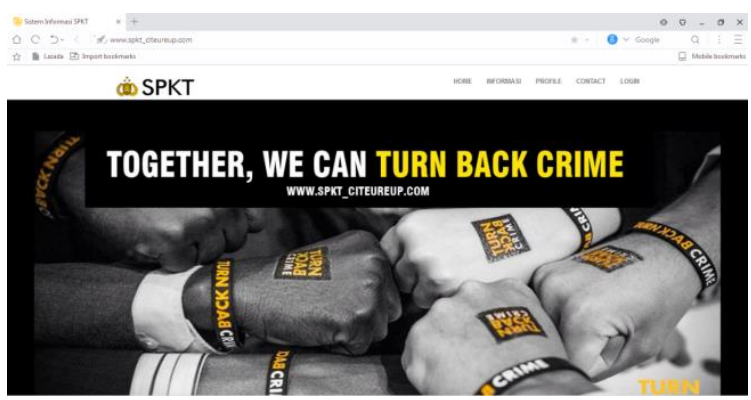

Gambar 7. Tampilan Menu Utama

2. Spesifikasi Rancangan Tampilan Program Menu Informasi

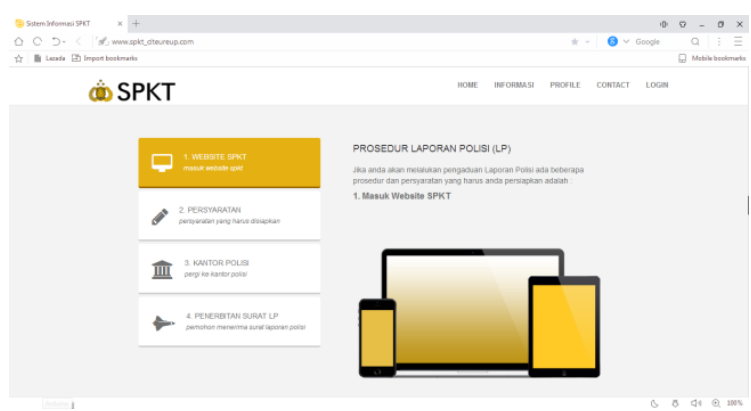

Gambar 8. Tampilan Menu Informasi

3. Spesifikasi Rancangan Tampilan Program Login.

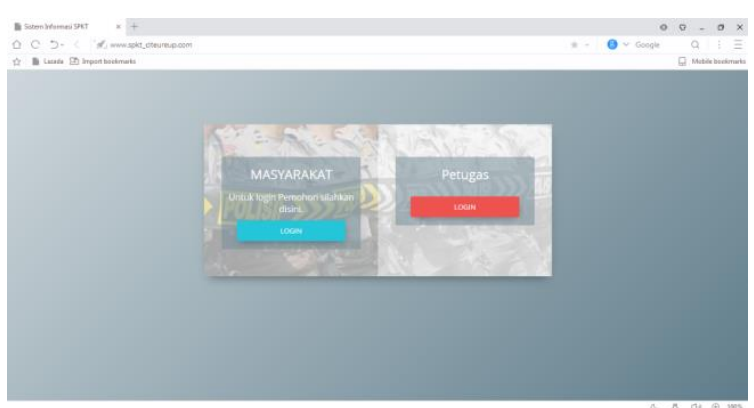

Gambar 9. Tampilan Menu Login User

4. Spesifikasi Rancangan Tampilan Program Registrasi. 


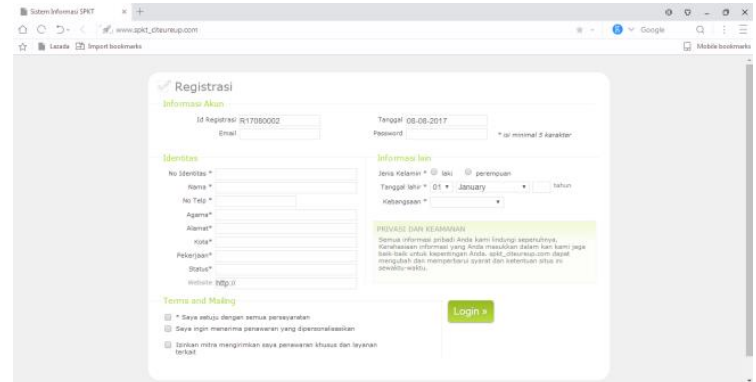

Gambar 10. Tampilan Menu Registrasi User

5. Spesifikasi Tampilan Program Login Pemohon.

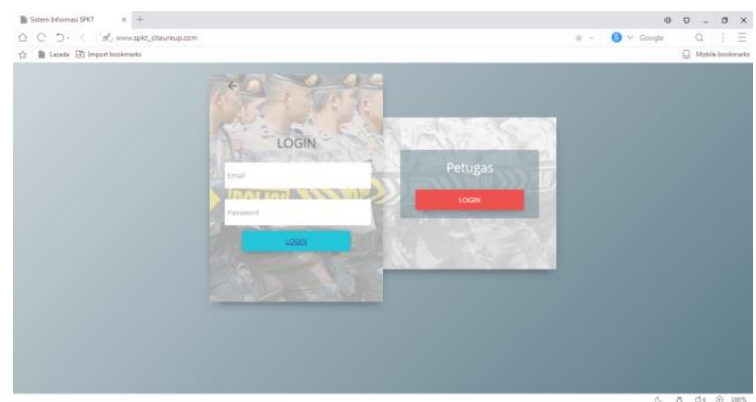

Gambar 11. Tampilan Menu Login Pemohon

6. Spesifikasi Tampilan Program Menu Pemohon.

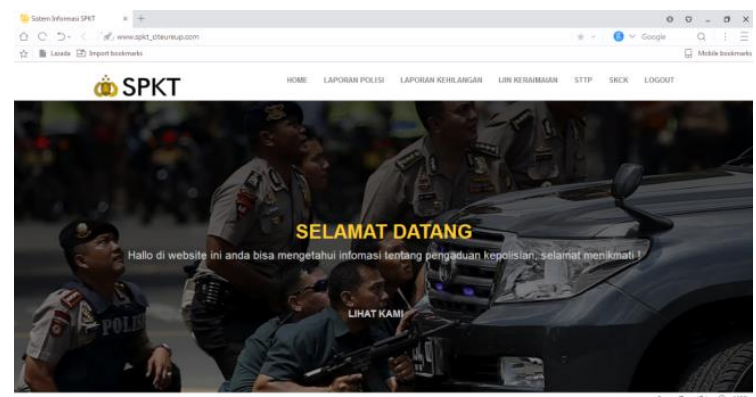

Gambar 12. Tampilan Menu Pemohon

7. Spesifikasi Tampilan Program Menu Laporan Polisi.

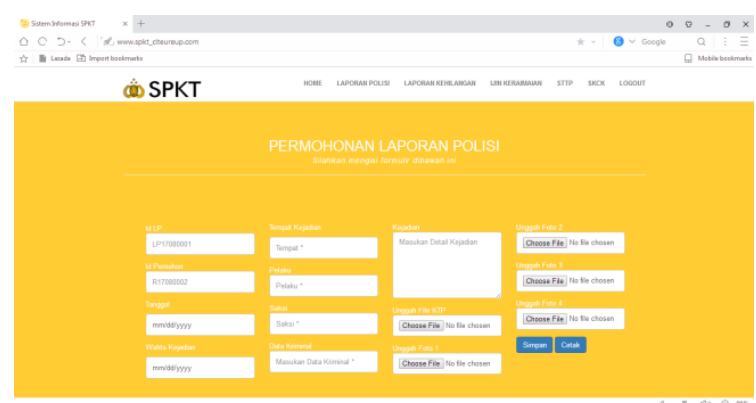

Gambar 13. Tampilan Menu Laporan Polisi

8. Spesifikasi Tampilan Program Menu Petugas.

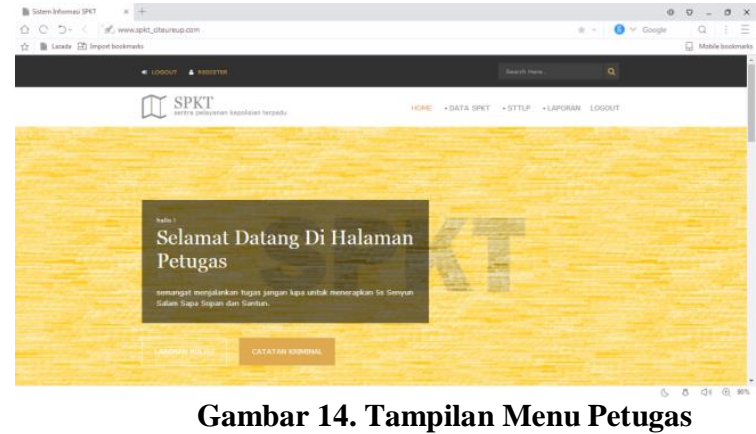

9. Spesifikasi Tampilan Program Menu Data Petugas.

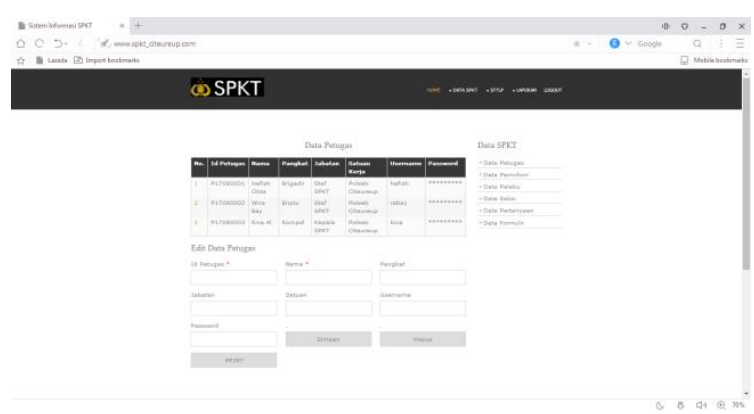

Gambar 15. Tampilan Menu Data Petugas

10. Spesifikasi Tampilan Program Laporan LP.

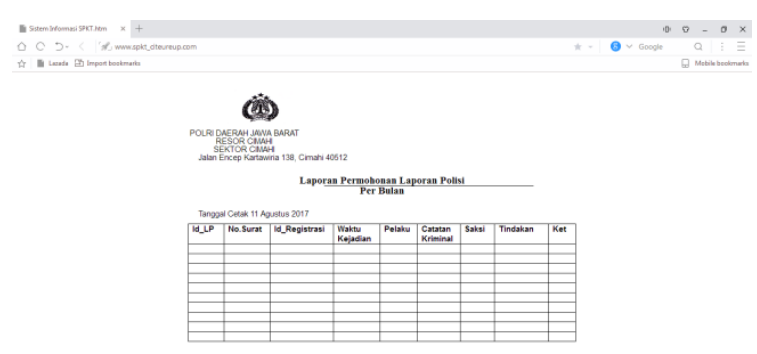

\section{Gambar 16. Tampilan Laporan LP IV. KESIMPULAN}

Pada Unit SPKT (Sentra Pelayanan Kepolisian Terpadu) Polsek Citeureup Cimahi setelah dilakukan penelitian dapat ditarik kesimpulan bahwa unit SPKT mempunyai masalah-masalah dengan sistem berjalan. Masalah-masalah tersebut diantaranya, kepolisian masih menggunakan sistem konvensional belum terkomputerisasi sehingga memungkinkan pada saat proses berlangsung terjadi kesalahan dalam pencatatan, kurang akuratnya laporan yang dibuat, keterlambatan dalam pencarian data yang diperlukan untuk pengolahan data permohonan STTLP (Surat Tanda Terima Laporan Polisi) menjadi kurang efektif, sementara kesulitan yang dihadapi masyarakat adalah kurangnya informasi persyaratan yang harus dilengkapi untuk membuat permohonan STTLP sehingga banyak 
pemohon berulang kali datang ke kantor polisi. Oleh sebab itu penulis mengusulkan sistem informasi SPKT berbasis $w e b$, agar masalah-masalah yang terjadi dengan sistem berjalan dapat ditanggulangi, yaitu :

1. Dapat mengatasi kemudahan dan kecepatan unit SPKT dalam melayani masyarakat dalam pembuatan STTLP setelah pendaftaran dan persyaratan di upload melalui web oleh pemohon .

2. Dapat mengatasi kemudahan petugas dalam pengolahan data SPKT karena proses penyimpanan, pengubahan, penghapusan, pencarian dan pengarsipan data menjadi lebih efektif dan efisien.

3. Memberikan kemudahan dalam sistem informasi SPKT kepada masyarakat untuk membuat permohonan STTLP, sehingga masyarakat tidak harus berulang kali datang ke kantor polisi untuk memenuhi persyaratan yang belum lengkap karena semua persyaratan di upload melalui website sehingga masyarakat tidak harus antre untuk membuat karena menggunakan sistem online bisa dilakukan dimana saja.

4. Pengawasan dapat secara langsung dilakukan oleh Kepala Administrasi SPKT dengan melihat laporan yang telah ada pada sistem yang terintegrasi, sehingga bisa di lihat kapanpun.

\section{DAFTAR PUSTAKA}

[1] Agustina, S. M. 2010. ShourtCourse Mendesain Website Dinamis dan Menarik dengan Adobe Dreamweaver CS5. Yogyakarta: C.V ANDI OFFSET.

[2] Darmawan. D, \& Permana, D. H. 2013. Desain dan Pemrograman Website. Bandung: PT Remaja Rosdakarya.

[3] Hendrajati, A. 2013. Rekayasa Perangkat Lunak SPKT polrestabes semarang. jurnal_13092.

[4] Jatnika, H. 2013. Pengantar Sistem Basis Data Memahami Konsep Dasar \& Tuntunan Praktis
Perancangan Database. Yogyakarta: C.V ANDI OFFSET

[5] Kristanto, A. 2008. Perancangan Sistem Informatika dan Aplikasinya. Yogyakarta: Graha Ilmu.

[6] Priyadi, Y. 2014. Kolaborasi SQL dan ERD. Yogyakarta: CV ANDI OFFSET.

[7] RachmatsyahAgus Dendi, Datia Merlini 2017 Perancangan Sistem Informasi Administrasi Surat Berbasis Desktop Pada Kantor Notaris Hoiril Masuli, Sh, M.KnJurnal SISFOKOM, Volume 06, Nomor 02, September 2017

[8] Rahardja, U., Rayeb, A. E., \& Saefullah, A. 2009. Siapa saja Bisa Membuat Website dengan CSS dan HTML. Yogyakarta: C.V ANDI OFFSET.

[9] Rosa A.S, \& Salahudin, M. 2015. Rekayasa perangkat lunak Berstruktur dab Berorientasi Objek. Bandung: Informatika Bandung.

[10] Sedarmayanti, P. S. 2013. Reformasi Administrasi Publik, Reformasi Birokrasi, Dan kepemimpinan Masa Depan. Bandung: PT Refika Aditama.

[11] Supriyanti, E., Warso, M. M., \& Minarsih, M. M. 2015. Pengaruh Kualitas Pelayanan dan fasilitas terhadap kepuasan masyarakat. Journal of Management.

[12] Wicaksono, H. 2016. Perancangan sistem informasi administrasi kependudukan . Bandung.

[13] Winarno, Zaki, \& Community, S. 2013. Buku sakti pemograman PHP. Jakarta: PT Elex Media Komputindo. 